Cardiopulmonary

Support and

Physiology

\title{
An evidence-based review of the practice of cardiopulmonary bypass in adults: A focus on neurologic injury, glycemic control, hemodilution, and the inflammatory response
}

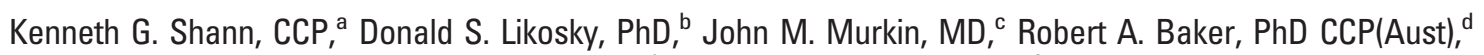

Yvon R. Baribeau, MD, ${ }^{e}$ Gordon R. DeFoe, CCP, ${ }^{b}$ Timothy A. Dickinson, MS, ${ }^{f}$ Timothy J. Gardner, MD, ${ }^{g}$ Hilary P. Grocott, MD, ${ }^{h}$ Gerald T. O'Connor, PhD, DSc, ${ }^{\mathrm{b}}$ David J. Rosinski, CCP, ${ }^{\mathrm{i}}$ Frank W. Sellke, MD, ${ }^{\mathrm{j}}$ and Timothy W. Willcox, CCP(Aust) ${ }^{\mathrm{k}}$

See related editorial on page 223.

Earn CME credits at http://cme.

丹 Supplemental material is available online.

From the Department of Cardiothoracic Surgery, ${ }^{\mathrm{a}}$ Montefiore-Einstein Heart Center, Bronx, NY; the Departments of Surgery, Medicine, and Community and Family Medicine, ${ }^{\mathrm{b}}$ Dartmouth Medical School, Hanover, NH; the Department of Anesthesiology and Perioperative Medicine, ${ }^{\mathrm{c}}$ London Health Sciences Center, London, Ontario, Canada; Cardiac Surgical Research Group, ${ }^{\mathrm{d}}$ Flinders Medical Centre, South Australia, Australia; the Department of Cardiothoracic Surgery, ${ }^{e}$ Catholic Medical Center, Manchester, NH; Fresenius Medical Care Extracorporeal Alliance, ${ }^{f}$ San Diego, Calif; Christina Care

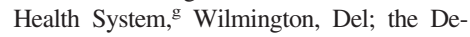
partment of Anesthesiology, ${ }^{\text {h }}$ Duke Medical Center, Durham, NC; the Department of Perfusion Services, ${ }^{i}$ University of Connecticut Health Center, Farmington, Conn; Beth Israel-Deaconess Medical Center, ${ }^{\mathrm{j}}$ Boston, Mass; and the Green Lane Cardiothoracic Surgical Unit, ${ }^{\mathrm{k}}$ Auckland City Hospital, Auckland, New Zealand.

Received for publication Dec 12, 2005; revisions received Jan 10, 2006; accepted for publication March 13, 2006.

Address for reprints: Donald S. Likosky, $\mathrm{PhD}$, Departments of Surgery and Community and Family Medicine, DartmouthHitchcock Medical Center, One Medical Center Dr, Lebanon, NH 03756 (E-mail: donald.likosky@dartmouth.edu).

J Thorac Cardiovasc Surg 2006;132:283-90

$0022-5223 / \$ 32.00$

Copyright $(\subsetneq 2006$ by The American Association for Thoracic Surgery

doi:10.1016/j.jtcvs.2006.03.027
$\mathrm{C}$ ardiopulmonary bypass (CPB) can be used during cardiac surgery to oxygenate and subsequently recirculate blood that has been diverted from the heart and lungs. The practice of CPB has changed-and continues to change-dramatically since its advent in the 1950s. Although structured reviews of the evidence supporting the practice of cardiac surgery have been in the literature for more than a decade and continue to be refined in the wake of new and emerging evidence, ${ }^{\mathrm{E} 1, \mathrm{E} 2}$ additional targeted reviews, focusing on issues such as minimizing the effect of the inflammatory response or minimizing neurologic injury, are warranted. ${ }^{\mathrm{E} 3-\mathrm{E} 5}$ Previous attempts, by Edwards and colleagues ${ }^{\mathrm{E} 6}$ and Bartels and associates ${ }^{\mathrm{E} 7}$ at synthesizing the evidence base to support the principles of $\mathrm{CPB}$ have selectively reviewed the cardiac surgery literature or focused on unique patient populations. Additionally, the development of these reviews has not involved all members of the clinical team, most notably the individuals tasked with operating the CPB circuit. This gap in knowledge is in stark contrast with the shared goal of the cardiac team, namely to improve the conduct of CPB to reduce the patient's risk of adverse outcomes caused by cardiac surgery.

Despite a preponderance of evidence supporting key principles of managing safe and effective CPB practice, wide variation in the use of technology and techniques for conducting CPB persists regionally and nationally. ${ }^{\mathrm{E}, \mathrm{E} 9}$ Variations in practice have previously been shown to be associated with increased costs, lengths of stay, neurologic injury, and mortality. ${ }^{1-3, \mathrm{E} 5, \mathrm{E} 10, \mathrm{E} 11}$ This variation might be attributed to clinical uncertainty or institutional or local practice standards. To reduce this unwanted practice variation, we must provide our clinical colleagues with critically evaluated and evidence-based review for conducting CPB.

What follows is an evidence-based review for conducting safe, patient-centered, and effective CPB practice. The authors have graded the level of evidence and classified the findings listed below by using the criteria promulgated by the American Heart Association and the American College of Cardiology Task Force on Practice Guidelines (Table 1). The development of these findings evolved from a structured MEDLINE search coupled with critical review of the peer-review literature and debates stemming from presentations at regional and national conferences, including the Connecticut Society of Perfusion (2004), Outcomes 2004: The Key West Meeting, New York State Society of Perfusion (2004), 12th Annual Meeting on Optimization of Blood Management During Surgery (2004), Florida State Society of Perfusion (2004), Tennessee State Society of Perfusion (2004), American Academy of Cardiovascular Perfusion $(2005,2006)$, and Outcomes 2005: The Key West Meeting.

The authors, a multidisciplinary group of physicians, epidemiologists, and perfusionists, seek to develop and share evidence-based reviews for conducting CPB through rigorous, structured, and expert-driven analysis of the peer-reviewed liter- 
Table 1. Methodologies and policies from the American College of Cardiology/American Heart Association Task Force on Practice Guidelines

\begin{tabular}{lc}
\hline Classification of recommendations & Level of evidence \\
\hline $\begin{array}{l}\text { Class I: Conditions for which there is evidence, general agreement, } \\
\text { or both that a given procedure or treatment is useful and } \\
\text { effective }\end{array}$ & Level A: Data derived from multiple randomized clinical trials \\
Class II: Procedure-treatment should be performed-administered & $\begin{array}{c}\text { Level B: Data derived from a single randomized trial or } \\
\text { nonrandomized studies } \\
\text { Class IIA: Additional studies with focused objectives needed }\end{array}$ \\
Class IIB: Additional studies with broad objectives needed; & \\
additional registry data would be helpful & \\
Class III: Procedure-treatment should not be performed-administered & \\
because it is not helpful and might be harmful & \\
\hline Adapted from Eagle KA, Guyton RA, Davidoff R, et al, ACC/AHA 2004 Guideline Update for Coronary Artery Bypass Graft Surgery: A Report of the American \\
College of Cardiology/American Heart Association Task Force on Practice Guidelines (Committee to Update the 1999 Guidelines for Coronary Artery Bypass \\
Graft Surgery); 2004.
\end{tabular}

ature. The mission of this group is to promote literaturesupported and evidence-based perfusion practice to improve patient care and enhance clinical outcomes.

We present this as the first of several documents regarding the development of evidence-based review for conducting CPB. In this initial document, regarding the development of evidence-based findings for CPB, we focus on neurologic protection, euglycemia, hemodilution, and the inflammatory response. These findings will be updated to ensure that they continue to be concurrent with emerging evidence and relevant to practicing clinicians.

\section{Methods}

The initiative to identify the evidence base and develop findings for perfusion practice evolved from conversations between 2 of the authors (KS, DR). Subsequent conversations between these and other investigators resulted in the development of our study's methodology.

We chose not to conduct a meta-analysis of the peer-reviewed literature, and instead, we adopted a process set forth by the American Heart Association and American College of Cardiology (http://www.acc.org/clinical/manual/manual_I.htm) for the development of evidence-based reviews of the peer-reviewed literature. In short, the group agreed to (1) determine and agree to the scope and clinical objectives, (2) define and conduct appropriate and comprehensive literature searches, (3) sort and evaluate the evidence, (4) synthesize and interpret the evidence, (5) write findings based on expert interpretation of the evidence, (6) assign classification of findings and strength of evidence, and (7) assemble the document. Critical to the success of this project was a detailed and thorough literature search conducted by an expert biomedical librarian (search strategy available by request). Searches were conducted for each of the agreed-upon topics, and results were posted on a customized Web site through the National Center for Biotechnology Information (http://www.ncbi.nlm.nih.gov/entrez/).

Expert reviewers accessed the saved searches through this Web site and used the criteria set forth by the American Heart Association and American College of Cardiology to develop the findings contained herein. The level and class of evidence was applied to each finding by using a structured literature search of nonanimal studies referenced in MEDLINE. Although animal studies might be referenced within this document, they were not used in the development of the findings. Findings were shared with all coinvestigators and reflect input gathered from presentations at regional, national, and international conferences. Findings for each section were written based on the guidance set forth by the American Heart Association and American College of Cardiology.

\section{Neurologic Protection}

Compared with a decade ago, greater numbers of patients of increasing age are surviving more extensive operations, with a shorter duration of hospitalization. ${ }^{\text {E12 }}$ Despite these advances, a number of fundamental clinical issues continue to be managed by clinical routine, rather than reflecting an optimized CPB strategy for reduction of central nervous system injury. This clinical routine is likely to result in missed opportunities for optimizing care based on the patient's risk of an adverse neurologic outcome.

\section{pH Management}

Of fundamental importance in the care of patients undergoing CPB is acid-base status, specifically related to $\mathrm{pH}$ management and $\mathrm{CO}_{2}$ regulation. Since the initial hypothesis that alpha-stat $\mathrm{pH}$ management would be associated with improved outcomes, ${ }^{4}$ there have been at least 3 independent prospective randomized trials demonstrating improved neurologic and neuropsychologic outcomes associated with alpha-stat $\mathrm{pH}$ management in adult patients undergoing moderately hypothermic CPB. ${ }^{1,5,6}$ Alpha-stat blood gas management preserves cerebral blood flow-metabolism coupling such that hypothermic-induced decreases in metabolic rate are accompanied by proportionate decreases in cerebral blood flow. ${ }^{4}$ The authors do recognize there might be specific circumstances, such as chronic hypercapnia, that might require a modification of this approach to preserve preoperative physiologic levels of $\mathrm{PCO}_{2}$. 


\section{pH Management}

The clinical team should manage adult patients undergoing moderate hypothermic CPB with alphastat $\mathrm{pH}$ management. (Class I, Level A)

\section{Hyperthermia}

As reported by Pugsley and coworkers, ${ }^{7}$ a patient's risk of neuropsychologic injury in the setting of coronary artery bypass grafting (CABG) surgery is in part attributed to the quantity of microemboli delivered to the brain. As reported by van der Linden and CasimirAhn, ${ }^{\text {E13 }}$ a high percentage of emboli occur during the early and late phases of cardiac surgery. At the time when patients are most likely to experience an ischemic event, they are typically perfused at warmer temperatures.

Most of the evidence documenting poorer outcomes in the setting of cerebral hyperthermia comes from the stroke literature. Hajat and colleagues ${ }^{\text {E14 }}$ previously identified an association between cerebral hyperthermia in the setting of stroke with increased morbidity and mortality. Ginsberg and Busto ${ }^{\mathrm{E} 15}$ elucidated the effect of hyperthermia in the setting of cerebral ischemia, identifying some of these mechanisms: (1) increased release of neurotransmitters, (2) increased free radical production, (3) breakdown of the bloodbrain barrier, (4) increased ischemic depolarizations in the focal ischemic penumbra, (5) impaired recovery of energy metabolism and inhibition of protein kinases, and (6) worsening of cytoskeletal proteolysis. Hajat and colleagues, ${ }^{\text {E14 }}$ in a meta-analysis of the effects of hyperthermia in the setting of stroke, reported increased morbidity and mortality among patients experiencing hyperthermia. In the setting of CABG surgery, Grocott and associates ${ }^{8}$ similarly found postoperative hyperthermia to be associated with greater neuropsychologic dysfunction. Similarly, Grigore and coworkers ${ }^{2}$ found greater neuropsychologic dysfunction in patients randomized to a faster rather than slower rewarming rate in the setting of CABG surgery. Interestingly, patients rewarmed at a faster rate were exposed to higher peak temperatures and a higher mean temperature of greater than $37^{\circ} \mathrm{C}$ than patients rewarmed slower with lower peak temperatures. Monitoring for and aggressively treating cerebral hyperthermia thus likely offers an opportunity to minimize the exacerbation of neurologic injury in the setting of CABG surgery.

Hypothermia is widely used during $\mathrm{CPB}$ to protect the brain and other vital organs by reducing the oxygen requirements of affected tissues. Hypothermic CPB, however, as reported by Insler and colleagues, ${ }^{\text {E16 }}$ requires a period of rewarming to avoid the adverse outcomes associated with postoperative hypothermia. Contemporary management of $\mathrm{CPB}$, which does not emphasize aggressive monitoring of temperatures, therefore potentially exposes the brain to periods of hyperthermia, as identified by Nathan and Lavallee $^{\mathrm{E} 17}$ and Cook and associates ${ }^{\mathrm{E} 18}$ separately. Although
Stone and coworkers ${ }^{\mathrm{E} 19}$ reported nasopharyngeal monitoring to match well to brain temperature compared with other monitoring sites, Cook and colleagues, ${ }^{\text {E18 }}$ Grocott and associates, ${ }^{\text {E20 }}$ Kaukuntla and colleagues, ${ }^{9}$ and Johnson and coworkers ${ }^{\mathrm{E} 21}$ have noted that it might underestimate jugular venous temperatures and thereby expose the brain to unintended hyperthermia. As documented by Kaukuntla and colleagues, ${ }^{9}$ without monitoring and attentive management, arterial inflow temperatures of the CPB circuit will likely exceed corporeal temperatures and expose the brain to subsequent hyperthermia. It would therefore be advantageous to at least monitor arterial inflow temperature. Caution must be encouraged here because recent work by Salah and associates ${ }^{\mathrm{E} 22}$ and Newland and coworkers ${ }^{\mathrm{E} 23}$ has suggested an underestimation of arterial inflow temperature while using conventional coupled temperature-monitoring devices.

Ten randomized controlled trials and 2 prospective cohort studies have evaluated neurologic outcomes associated with temperature management during $\mathrm{CPB}$. Of the 10 randomized controlled trials, 6 (McLean and colleagues, ${ }^{\text {E24 }}$ The Warm Heart Investigators, ${ }^{\text {E25 }}$ Engelman and associates, ${ }^{\text {E26 }}$ Grigore and coworkers, ${ }^{\text {E27 }}$ Plourde and colleagues, ${ }^{\mathrm{E} 28}$ and Birdi and associates ${ }^{\mathrm{E} 29}$ ) concluded that there was no difference between normothermic and hypothermic CPB, 3 (Martin and coworkers, ${ }^{\mathrm{E} 30}$ Mora and colleagues, ${ }^{\mathrm{E} 31}$ and Regragui and associates ${ }^{\mathrm{E} 32}$ ) reported poorer outcomes with normothermic CPB, and 1 (Grimm and coworkers ${ }^{\mathrm{E} 33}$ ) found poorer outcomes with hypothermic CPB. Three nonrandomized studies reported conflicting findings regarding temperature management and neurologic outcomes, with 1 (Gaudino and colleagues ${ }^{\mathrm{E} 34}$ ) concluding worse outcome with normothermic CPB and 2 (Singh and associates ${ }^{\mathrm{E} 35}$ and Christenson and coworkers ${ }^{\mathrm{E} 36}$ ) showing no statistical difference. Differences in these findings likely are attributed to heterogeneity in study design, lack of standardized temperature-monitoring sites, and potentially unrecognized cerebral hyperthermia among study patients, regardless of temperature management strategy. The study by Nathan and colleagues ${ }^{10}$ is noteworthy in that the group randomized to separate from bypass at $34^{\circ} \mathrm{C}$ (hypothermic group) most likely avoided any transient hyperthermia. They found a reduction in neuropsychologic deficits in this group compared with the group rewarmed to $37^{\circ} \mathrm{C}$, without a concomitant increase in morbidity and mortality.

The measurement and tracking of perioperative hyperthermia is essential for neurologic protection. Cerebral temperatures exceeding $37^{\circ} \mathrm{C}$ might expose patients to unnecessary neurologic risk. During $\mathrm{CPB}$, reliable and accurate measurement of arterial inflow temperatures is imperative. Preventing hyperthermia and subsequent risk of neurologic injury in this setting might occur through reliable measurement and strict avoidance of perfusion temperatures exceeding $37^{\circ} \mathrm{C}$. 


\section{Avoidance of Hyperthermia}

Limiting arterial line temperature to $37^{\circ} \mathrm{C}$ might be useful for avoiding cerebral hyperthermia. (Class IIa, Level B)

"Coupled temperature" ports for all oxygenators should be checked for accuracy and calibrated.

\section{Minimizing Return of Pericardial Suction Blood}

As noted separately by Caguin and Carter, ${ }^{11}$ Clark and associates, ${ }^{\mathrm{E} 38}$ and Siderys and coworkers, ${ }^{\mathrm{E} 39}$ reinfusion of cardiotomy suction blood exposed to pericardial and mediastinal surfaces in patients undergoing CPB is associated with postoperative neurologic injury, attributed in part to increased levels of hemolysis and fat in scavenged blood. Brooker and colleagues ${ }^{\mathrm{E} 40}$ identified the association between cerebral lipid microemboli after CPB with the reinfusion of cardiotomy suction blood in a canine model. Additionally, Appelblad and Engstrom, ${ }^{\mathrm{E} 41} \mathrm{Kaza}$ and associates, ${ }^{12}$ Jewell and coworkers, ${ }^{13}$ and de Vries and colleagues ${ }^{\mathrm{E} 42}$ identified pericardial suction blood as the primary source of fat emboli during CPB. De Hann and associates ${ }^{14}$ demonstrated that reinfusion of pericardial suction blood exacerbated activation of markers of coagulation and fibrinolysis and resulted in increased blood loss. Spanier and coworkers ${ }^{\mathrm{E} 43}$ documented increased endotoxin levels with the reinfusion of pericardial suction blood during $\mathrm{CPB}$, whereas research conducted by Chung and colleagues, ${ }^{15}$ Johnell and associates, ${ }^{\text {E44 }}$ and Weerwind and coworkers $^{\mathrm{E} 45}$ reported the following sequelae: thrombin generation and activation of the coagulation, fibrinolytic, and inflammatory pathways.

To reduce systemic inflammatory response and exposure to fat emboli, techniques to minimize shed mediastinal blood through improved intraoperative hemostasis should be advocated, and where possible, reinfusion of pericardial suction blood should be avoided. Secondary filtration of pericardial suction blood, as well as treatment with a blood cell processor with or without additional filtration before return to the extracorporeal circuit, has resulted in reduced reinfusion of fat emboli, as noted by Kaza and associates, ${ }^{12}$ Jewell and coworkers, ${ }^{13}$ de Vries and colleagues, ${ }^{\mathrm{E} 42}$ and Kincaid and associates. ${ }^{\text {E46 }}$

\section{Return of Pericardial Suction Blood}

Direct reinfusion to the CPB circuit of unprocessed blood exposed to pericardial and mediastinal surfaces should be avoided. (Class I, Level B)

Blood cell processing and secondary filtration can be considered to decrease the deleterious effects of reinfused shed blood. (Class IIb, Level B)

\section{Aortic Assessment}

As noted by Likosky and associates, ${ }^{\text {E47 }}$ among others, cerebral atheroemboli account for the majority of type I (stroke) outcomes after CABG surgery, with noncalcific plaque likely the greatest contributor of these emboli. Davila-Roman and colleagues ${ }^{16}$ reported that noncalcific plaque, unfortunately, is least likely to be identified by intraoperative surgical palpation of the aorta before instrumentation. Blauth and coworkers ${ }^{\mathrm{E} 48}$ and DavilaRoman and associates ${ }^{\mathrm{E} 49}$ have shown that advanced age, diabetes mellitus, and vascular disease, all conditions that are well-known risk factors for perioperative stroke, are also predictors of advanced aortic atherosclerosis and attendant systemic atheroemboli. Mizuno and colleagues ${ }^{\mathrm{E} 50}$ and Davila-Roman and associates ${ }^{\mathrm{E} 49}$ identified significant atherosclerosis (defined as intimal thickening $>5 \mathrm{~mm}$ in the aortic arch), present in up to $20 \%$ of patients undergoing $\mathrm{CABG}$, to be associated with an increased risk of stroke after $\mathrm{CABG}$, presumably through an embolic mechanism, as suggested by Djaiani and colleagues. ${ }^{\text {E51 }}$ As reported by Davila-Roman and colleagues, ${ }^{16}$ epiaortic ultrasonography is significantly more sensitive than transesophageal echocardiography (TEE) for identification of atherosclerosis of the ascending aorta, whereas Sylvris and associates ${ }^{17}$ and Royse and coworkers ${ }^{18}$ have identified both ultrasonographic techniques to be superior to palpation. Epiaortic ultrasonography and TEE provide complementary information regarding thoracic aortic atherosclerosis. Many reports (Davila-Roman and associates, ${ }^{\mathrm{E} 49}$ Trehan and colleagues, ${ }^{19}$ Gold and coworkers, ${ }^{\text {E52 }}$ and Mackensen and associates ${ }^{20}$ ) have highlighted a protective effect, in terms of prevention of atheroembolic complications, with the modification of surgical technique on the basis of results of intraoperative epiaortic ultrasonography and TEE in elderly patients undergoing cardiac procedures. As reported by Gold and coworkers, ${ }^{\text {E52 }}$ Trehan and colleagues, ${ }^{19}$ Ribakove and associates, ${ }^{\text {E53 }}$ and Baribeau and coworkers, ${ }^{\text {E54 }}$ epiaortic ultrasonography and TEE might facilitate the reduction of neurologic injury through the identification of areas free from atherosclerosis for aortic cannulation, avoidance of the ascending aorta entirely through femoral or axillary artery sites, or use of an off-pump technique.

\section{Aortic Assessment}

In patients undergoing $C P B$ at increased risk of adverse neurologic events, strong consideration should be given to intraoperative TEE or epiaortic ultrasonographic scanning of the aorta: (1) to detect nonpalpable plaque (Class I, Level B) and (2) for reduction of cerebral emboli (Class IIa, Level B).

\section{Arterial Line Filtration}

The presence of microemboli (gaseous or particulate) and foreign material in the CPB circuit and subsequent delivery to the patient through the arterial line has resulted in the incorporation of arterial filters into CPB circuits. Although in vitro and in vivo studies by Taylor and coworkers ${ }^{\mathrm{E} 55}$ and Loop and associates ${ }^{21}$ respectively, have provided evidence for benefits associated with the inclusion of these filters into 
the arterial line, their routine use in the CPB circuit is not universal. $^{\text {E56 }}$

Pugsley and colleagues ${ }^{7}$ and Padayachee and coworkers $^{22}$ demonstrated a reduction in embolic load delivered to the brain with the inclusion of arterial line filters, whereas Sellman and associates ${ }^{23}$ similarly demonstrated a reduction in emboli distal to the arterial line filter. Padayachee and coworkers $^{22}$ additionally demonstrated an advantage with 25 - versus $40-\mu \mathrm{m}$ filters in removing gaseous microemboli.

Most studies reporting on the benefits of filtration were performed with bubble oxygenators. In one randomized trial Pugsley and colleagues ${ }^{7}$ showed a reduction in neuropsychologic injury with a $40-\mu \mathrm{m}$ arterial line filter, a finding that both Aris and coworkers ${ }^{\text {E57 }}$ and Sellman and associates ${ }^{\mathrm{E} 8}$ had been unable to demonstrate. In lieu of additional studies focused specifically on the association between the use of arterial filters and neurologic injury, the association between embolic load and neuropsychologic outcome has been demonstrated through reports by Pugsley and colleagues, ${ }^{7}$ Clark and coworkers, ${ }^{\text {E59 }}$ and Stump and associates. $^{\text {E60 }}$

\section{Arterial Filtration}

Arterial line filters should be incorporated in the $C P B$ circuit to minimize the embolic load delivered to the patient. (Class I, Level A).

\section{Maintenance of Euglycemia}

As argued by Murkin, ${ }^{\text {E61 }}$ there is both experimental and clinical evidence that hyperglycemia is associated with exacerbation of neurologic injury, as well as a variety of other adverse outcomes, including wound infection and mortality, among critically ill patients. McAlister and colleagues ${ }^{\mathrm{E} 62}$ correlated average blood glucose levels on the first postoperative day after $\mathrm{CABG}$ surgery with a variety of adverse outcomes (stroke, myocardial infarction, septic complication, or death). For each $1-\mathrm{mmol} / \mathrm{L}$ increase above 6.1 $\mathrm{mmol} / \mathrm{L}(1 \mathrm{mmol}=18 \mathrm{mg} / \mathrm{dL})$, the risk of these outcomes increased by $17 \%$. In a prospective study of critically ill patients, Finney and associates ${ }^{\text {E63 }}$ suggested that the control of blood glucose levels, rather than insulin levels per se, accounts for apparent benefits in mortality. In a singlecenter study by Latham and coworkers ${ }^{\text {E64 with an }}$ accompanying editorial by Dellinger, ${ }^{\text {E65 }}$ the greatest risk for surgical site infection among all patients undergoing cardiothoracic surgery occurred among those with either postoperative hyperglycemia (blood glucose levels $>200 \mathrm{mg} /$ dL) or undiagnosed diabetes. Estrada and associates ${ }^{24}$ reported on a historic cohort of 1574 patients undergoing CABG between 1998 and 1999 within a single institution. The authors found perioperative hyperglycemia to be associated with both longer postoperative length of stay and increased hospitalization charges/costs among diabetic and nondiabetic patients.
Furnary and colleagues ${ }^{25}$ demonstrated, in a nonrandomized, prospective interventional study of 4864 patients undergoing cardiac procedures, that perioperative hyperglycemia is directly associated with increased rates of death, deep sternal wound infections, length of stay, and hospital costs. The work from Furnary and colleagues, ${ }^{25, E 66-E 68}$ Estrada and associates, ${ }^{24}$ and McAlister and colleagues ${ }^{\mathrm{E} 62}$ suggests that a target glucose range of less than $150 \mathrm{mg} / \mathrm{dL}$ is favorable for maintaining euglycemia. Recent evidence by Carvalho and coworkers ${ }^{\mathrm{E} 69}$ suggests that maintenance of intraoperative blood glucose levels might be managed in both diabetic and nondiabetic patients with the use of an aggressive insulin dosing strategy during cardiac surgery.

Ouattra and associates, ${ }^{\text {E70 }}$ in an observational study of 200 consecutive diabetic patients undergoing cardiac surgery, demonstrated that poor intraoperative control of blood glucose concentrations was associated with an increased incidence of in-hospital morbidity (including cardiovascular, infectious, neurologic respiratory, neurologic, and renal). Two additional observational studies (Gandhi and coworkers ${ }^{26}$ and Doenst and associates ${ }^{27}$ ), representing a combined 6689 patients undergoing cardiac surgery, demonstrated a relationship between intraoperative hyperglycemia and mortality.

In a systematic review of the evidence authored by Garber and coworkers, ${ }^{\text {E71 }}$ the position statement on inpatient diabetes and metabolic control, sponsored by The American College of Endocrinology, the American Association of Clinical Endocrinologists, and the cosponsoring organizations (including the Society of Thoracic Surgeons), supports the need for early detection and aggressive management of hyperglycemia in the hospital setting for improving patient outcomes.

Groban and associates ${ }^{\mathrm{E} 72}$ identified increased blood sugar as a routine accompaniment to $\mathrm{CPB}$, reflecting in part the difficulty in effectively treating hyperglycemia, especially in the presence of intense gluconeogenesis and insulin resistance, such as during CPB. As suggested by Murkin, ${ }^{\text {E61 }}$ avoidance or limitation of some of the following might effectively limit hyperglycemia with the expectation of enhanced neurologic outcomes: (1) glucose containing intravenous, cardioplegic, and pump-priming solutions; (2) enhanced awareness and treatment of catecholamine-induced hyperglycemia; and (3) more aggressive insulin dosing strategies.

Maintenance of Euglycemia

The clinical team should maintain perioperative blood glucose concentration within an institution's normal clinical range in all patients, including nondiabetic subjects. (Class I, Level B)

\section{Modified Extracorporeal Circuits Hemodilution}

Currently, the advancement of perfusion technology has led to the development and use of condensed circuits and bio- 
passive surface modification. The goal of these efforts has been to reduce the systemic inflammatory response syndrome (SIRS) while preserving platelet function and minimizing the need for allogeneic blood products.

Several large observational studies (DeFoe and colleagues, ${ }^{3}$ Habib and associates, ${ }^{28}$ Fang and coworkers, ${ }^{29}$ and Karkouti and colleagues ${ }^{30}$ ) have identified an association between nadir hematocrit (HCT) values and risk of in-hospital mortality and other adverse events. DeFoe and colleagues $^{3}$ reported results from a multicenter study of 6980 patients undergoing isolated CABG surgery. Patients experiencing a single $\mathrm{HCT}$ value of $19 \%$ or less during $\mathrm{CPB}$ had more than twice the mortality as patients with a nadir HCT value of $25 \%$. Furthermore, the lowest HCT value during $\mathrm{CPB}$ was significantly associated with increased intraoperative or postoperative placement of an intra-aortic balloon pump and return to CPB after attempted separation. Habib and associates ${ }^{28}$ retrospectively analyzed 5000 patients undergoing cardiac operations with CPB and found that stroke, myocardial infarction, low cardiac output, cardiac arrest, renal failure, prolonged ventilation, pulmonary edema, reoperation caused by bleeding, sepsis, and multiorgan failure were all significantly and systematically increased as the lowest HCT value decreased to less than $22 \%$. In a study of 2738 patients undergoing isolated CABG, Fang and coworkers ${ }^{29}$ found an increased risk of postoperative death (odds ratio, 2.7) in patients with HCT values of $14 \%$ or less, and in a high-risk subgroup there was an increased risk (odds ratio, 2.2) when the HCT value during CPB was less than $17 \%$. Karkouti and colleagues ${ }^{30}$ examined a series of 10,949 patients undergoing on-pump CABGs and found that the risk of a perioperative stroke increased $10 \%$ with each percentage decrease in nadir HCT value $(95 \%$ confidence interval, $4 \%-18 \% ; P=.002)$.

Additional studies (Karkouti and associates ${ }^{\mathrm{E} 73}$ and Swaminathan and coworkers ${ }^{\mathrm{E} 74}$ ) have also identified the association between nadir HCT values and renal injury. Karkouti and associates ${ }^{\mathrm{E73}}$ analyzed 9080 consecutive patients undergoing cardiac operations with $\mathrm{CPB}$ and found an independent and nonlinear relationship between the nadir HCT value during CPB and acute renal failure, necessitating dialysis support. Swaminathan and coworkers, ${ }^{\text {E73 }}$ in a study of 1404 patients undergoing primary elective CABG, found both a significant interaction between the lowest HCT value during CPB and body weight and between HCT value and postoperative creatinine increase level.

The observations listed above warrant the application of techniques to reduce the incidence of low HCT values. Several studies (McCusker and associates, ${ }^{\mathrm{E} 75}$ Cormack and colleagues, ${ }^{\mathrm{E} 76}$ Beholz and coworkers, ${ }^{\mathrm{E} 77}$ van Boven and associates, ${ }^{\text {E78 }}$ Takai and colleagues, ${ }^{\text {E79 }}$ and Shapira and coworkers ${ }^{\mathrm{E} 80}$ ) have illustrated that a reduction in surface area-priming volume of the $\mathrm{CPB}$ circuit reduces the fre- quency of low HCT values and subsequently reduces the incidence of allogeneic blood transfusions. Additionally, as evidenced by Rosengart and associates, ${ }^{\text {E1 }}$ Balachandran and colleagues, ${ }^{\mathrm{E} 82}$ and Petry and coworkers, ${ }^{\mathrm{E} 83}$ the technique of retrograde autologous priming of the $\mathrm{CPB}$ circuit is an effective means to decrease significantly hemodilution and the frequency of red cell transfusion during cardiac operations. As documented by Speiss, ${ }^{\text {E84 }}$ the untoward effects of allogeneic blood transfusions have been well documented in more than 3000 articles published in the medical literature. The adverse sequelae of transfusing red blood cells include infection (Chelemer and colleagues ${ }^{\mathrm{E} 85}$ and Leal-Noval and coworkers $\left.{ }^{\mathrm{E} 86}\right)$, renal injury and acute renal failure (Habib and coworkers ${ }^{\mathrm{E} 87}$ ), increased length of stay (Leal-Noval and coworkers, ${ }^{\text {E86 }}$ Vamvakas and Carven, ${ }^{\mathrm{E} 88}$ and Fransen and associates ${ }^{\mathrm{E} 89}$ ), and mortality (Leal-Noval and coworkers ${ }^{\mathrm{E} 86}$ and Michalopoulos and associates ${ }^{\mathrm{E} 90}$ ).

Kuduvalli and colleagues ${ }^{31}$ prospectively studied 3024 patients undergoing CABG and concluded that transfusion increased both 30 -day $(1.9 \%$ vs $1.1 \%, P<.05)$ and 1 -year mortality (adjusted hazard ratio, $1.88 ; 95 \%$ confidence interval, 1.23-3.00; $P<.01) .{ }^{31}$ Engoren and coworkers ${ }^{\mathrm{E} 91}$ examined the long-term effects of transfusion and found it to be a significant predictor of mortality at 5 years.

\section{Reduction of Hemodilution}

Efforts should be made to reduce hemodilution, including reduction of prime volume, to avoid subsequent allogeneic blood transfusion. (Class I, Level A)

\section{Attenuation of the Inflammatory Response}

The risk of SIRS and complement activation caused by CPB has been well described by Kirklin and associates ${ }^{\mathrm{E} 92}$ and Ascione and coworkers. ${ }^{\text {E93 }}$ Previous research by Ishikawa and colleagues, ${ }^{\text {E94 }}$ Striggow and associates, ${ }^{\text {E95 }}$ and Baufreton and coworkers ${ }^{\mathrm{E} 96}$ has reported the association between the inflammatory processes and exacerbation of ischemic brain injury by various mechanisms, including increased capillary permeability, complement activation, neutrophil activation, and protease-activated receptor upregulation. Blood contact with nonbiocompatible surfaces of the CPB circuit was implicated by Butler and associates ${ }^{\mathrm{E} 5}$ as a cause of the SIRS. A number of commercially available extracorporeal devices, including biocompatible surface coatings, condensed (miniaturized) extracorporeal circuits, and leukocyte-depleting filters, have demonstrated a suppression of the inflammatory response to extracorporeal circulation and improved outcomes. Administration of specific anti-inflammatory pharmacologics has also been associated, by Sedrakyan and coworkers ${ }^{32}$ and Asimakopoulos and colleagues, ${ }^{\text {E97 }}$ with decreased inflammatory processes and improved clinical outcomes.

The decrease in the incidence of SIRS with the use of biocompatible surface technology is well documented by 
Saito and associates, ${ }^{\text {E98 }}$ Videm and coworkers, ${ }^{\text {E99 }}$ Fromes and colleagues, ${ }^{\text {E100 }}$ and Moen and associates. ${ }^{\text {E101 }}$ In addition, Defraigne and coworkers ${ }^{\mathrm{E} 102}$ and Rubens and colleagues ${ }^{\mathrm{E} 103}$ documented platelet preservation with the use of biocompatible surface additive-coated CPB circuits. Although several randomized clinical trials (Dickinson and colleagues, ${ }^{\text {E104 }}$ Mahoney and Lemole, ${ }^{33}$ McCarthy and coworkers, ${ }^{\text {E } 105}$ Mongero and associates, ${ }^{\text {E106 }}$ and Ranucci and colleagues $^{34}$ ) demonstrated improved outcomes with the use of biocompatible circuits, one by Muehrcke and associates $^{\mathrm{E} 107}$ was unequivocal in its findings. Ranucci and colleagues ${ }^{34}$ conducted a multicenter randomized trial evaluating the effect of heparin-coated circuits on clinical outcomes among 886 patients undergoing cardiac operations. Heparin-coated circuits resulted in a shorter intensive care unit (ICU) and postoperative length of stay and fewer "severely impaired clinical outcomes" (defined as ICU length of stay $>5$ days or death). McCarthy and coworkers ${ }^{\mathrm{E} 105}$ randomized 350 patients undergoing $\mathrm{CABG}$ reoperations with or without valve operations to receive either heparincoated or uncoated CPB circuits. The investigators' protocol included full-dose heparin, an open reservoir, and cardiotomy suction. The percentage of major bleeding episodes was significantly less with heparin-coated circuits. In a prospective randomized study of 61 patients undergoing elective cardiac surgery with $\mathrm{CPB}$, Heyer and cowork$\mathrm{ers}^{\mathrm{E} 108}$ found that patients treated with heparin-bonded CPB circuits had less postoperative cognitive dysfunction. Furthermore, a meta-analysis by Mahoney ${ }^{\mathrm{E} 109}$ has provided evidence of clinical benefits and cost savings with the use of heparin-bonded circuits. Finally, the combination of a condensed circuit with biocompatible surface additive coating has been associated (McCusker and associates, ${ }^{\mathrm{E} 75}$ Fromes and coworkers, ${ }^{\mathrm{E} 100}$ and Wiesenack and colleagues ${ }^{35}$ ) with reduced ventilator time, ICU and hospital length of stay, and transfusion requirements.

\section{Attenuation of the Inflammatory Response}

Reduction of circuit surface area and the use of biocompatible surface-modified circuits might be useful-effective at attenuating the systemic inflammatory response to $C P B$ and improving outcomes. (Class IIa, Level B)

\section{Discussion}

We have made every effort to develop findings for perfusion practice that are grounded in evidence-based medicine. We adopted a previously validated method for explicitly reviewing and grading the level and class of evidence as it relates to neurologic injury, euglycemia, hemodilution, and the inflammatory response. These findings will be updated on a routine basis, including the addition of other practice items, to keep them contemporaneous with the peer- reviewed medical literature and useful and pertinent to practicing clinicians.

We gratefully acknowledge the contributions of the following individuals: Robert Groom, Charles Krumholz, Alfred Stammers, David Stump, and Pamela Bagley.

\section{References}

1. Murkin JM, Martzke JS, Buchan AM, Bentley C, Wong CJ. A randomized study of the influence of perfusion technique and $\mathrm{pH}$ management strategy in 316 patients undergoing coronary artery bypass surgery. II. Neurologic and cognitive outcomes. J Thorac Cardiovasc Surg. 1995;110:349-62.

2. Grigore AM, Grocott HP, Mathew JP, Phillips-Bute B, Stanley TO, Butler A, et al. The rewarming rate and increased peak temperature alter neurocognitive outcome after cardiac surgery. Anesth Analg. 2002;94:4-10.

3. DeFoe GR, Ross CS, Olmstead EM, Surgenor SD, Fillinger MP, Groom RC, et al. Lowest hematocrit on bypass and adverse outcomes associated with coronary artery bypass grafting. Northern New England Cardiovascular Disease Study Group. Ann Thorac Surg. 2001; 71:769-76.

4. Murkin JM, Farrar JK, Tweed WA, McKenzie FN, Guiraudon G. Cerebral autoregulation and flow/metabolism coupling during cardiopulmonary bypass: the influence of $\mathrm{PaCO} 2$. Anesth Analg. 1987;66: 825-32.

5. Stephan H, Weyland A, Kazmaier S, Henze T, Menck S, Sonntag H. Acid-base management during hypothermic cardiopulmonary bypass does not affect cerebral metabolism but does affect blood flow and neurological outcome. Br J Anaesth. 1992;69:51-7.

6. Patel RL, Turtle MR, Chambers DJ, James DN, Newman S, Venn GE. Alpha-stat acid-base regulation during cardiopulmonary bypass improves neuropsychologic outcome in patients undergoing coronary artery bypass grafting. J Thorac Cardiovasc Surg. 1996;111:1267-79.

7. Pugsley W, Klinger L, Paschalis C, Treasure T, Harrison M, Newman $\mathrm{S}$. The impact of microemboli during cardiopulmonary bypass on neuropsychological functioning. Stroke. 1994;25:1393-9.

8. Grocott HP, Mackensen GB, Grigore AM, Mathew J, Reves JG, Phillips-Bute B, et al. Postoperative hyperthermia is associated with cognitive dysfunction after coronary artery bypass graft surgery. Stroke. 2002;33:537-41.

9. Kaukuntla H, Harrington D, Bilkoo I, Clutton-Brock T, Jones T, Bonser RS. Temperature monitoring during cardiopulmonary bypass-do we undercool or overheat the brain? Eur J Cardiothorac Surg. 2004;26:580-5.

10. Nathan HJ, Wells GA, Munson JL, Wozny D. Neuroprotective effect of mild hypothermia in patients undergoing coronary artery surgery with cardiopulmonary bypass: a randomized trial. Circulation. 2001; 104:I85-91.

11. Caguin F, Carter MG. Fat embolization with cardiotomy with the use of cardiopulmonary bypass. J Thorac Cardiovasc Surg. 1963;46: $665-72$.

12. Kaza AK, Cope JT, Fiser SM, Long SM, Kern JA, Kron IL, et al. Elimination of fat microemboli during cardiopulmonary bypass. Ann Thorac Surg. 2003;75:555-9.

13. Jewell AE, Akowuah EF, Suvarna SK, Braidley P, Hopkinson D, Cooper G. A prospective randomised comparison of cardiotomy suction and cell saver for recycling shed blood during cardiac surgery. Eur J Cardiothorac Surg. 2003;23:633-6.

14. de Haan J, Boonstra PW, Monnink SH, Ebels T, van Oeveren W. Retransfusion of suctioned blood during cardiopulmonary bypass impairs hemostasis. Ann Thorac Surg. 1995;59:901-7.

15. Chung JH, Gikakis N, Rao AK, Drake TA, Colman RW, Edmunds LH Jr. Pericardial blood activates the extrinsic coagulation pathway during clinical cardiopulmonary bypass. Circulation. 1996;93:2014-8.

16. Davila-Roman VG, Phillips KJ, Daily BB, Davila RM, Kouchoukos NT, Barzilai B. Intraoperative transesophageal echocardiography and epiaortic ultrasound for assessment of atherosclerosis of the thoracic aorta. J Am Coll Cardiol. 1996;28:942-7. 
17. Sylivris S, Calafiore P, Matalanis G, Rosalion A, Yuen HP, Buxton $\mathrm{BF}$, et al. The intraoperative assessment of ascending aortic atheroma: epiaortic imaging is superior to both transesophageal echocardiography and direct palpation. J Cardiothorac Vasc Anesth. 1997;11:704-7.

18. Royse C, Royse A, Blake D, Grigg L. Screening the thoracic aorta for atheroma: a comparison of manual palpation, transesophageal and epiaortic ultrasonography. Ann Thorac Cardiovasc Surg. 1998;4:347-50.

19. Trehan N, Mishra M, Dhole S, Mishra A, Karlekar A, Kohli VM. Significantly reduced incidence of stroke during coronary artery bypass grafting using transesophageal echocardiography. Eur J Cardiothorac Surg. 1997;11:234-42.

20. Mackensen GB, Ti LK, Phillips-Bute BG, Mathew JP, Newman MF, Grocott HP. Cerebral embolization during cardiac surgery: impact of aortic atheroma burden. Br J Anaesth. 2003;91:656-61.

21. Loop FD, Szabo J, Rowlinson RD, Urbanek K. Events related to microembolism during extracorporeal perfusion in man: effectiveness of in-line filtration recorded by ultrasound. Ann Thorac Surg. 1976; 21:412-20.

22. Padayachee TS, Parsons S, Theobold R, Gosling RG, Deverall PB. The effect of arterial filtration on reduction of gaseous microemboli in the middle cerebral artery during cardiopulmonary bypass. Ann Thorac Surg. 1988;45:647-9.

23. Sellman M, Ivert, T, Stensved P, Hogberg M, Semb B. Doppler ultrasound estimation of microbubbles in the arterial line during extracorporeal circulation. Perfusion. 1990;5:23-32.

24. Estrada CA, Young JA, Nifong LW, Chitwood WR Jr. Outcomes and perioperative hyperglycemia in patients with or without diabetes mellitus undergoing coronary artery bypass grafting. Ann Thorac Surg. 2003;75:1392-9.

25. Furnary AP, Wu Y, Bookin SO. Effect of hyperglycemia and continuous intravenous insulin infusions on outcomes of cardiac surgical procedures: the Portland Diabetic Project. Endocr Pract. 2004;10(suppl 2):21-33.

26. Gandhi GY, Nuttall GA, Abel MD, Mullany CJ, Schaff HV, Williams $\mathrm{BA}$, et al. Intraoperative hyperglycemia and perioperative outcomes in cardiac surgery patients. Mayo Clin Proc. 2005;80:862-6.
27. Doenst T, Wijeysundera D, Karkouti K, Zechner C, Maganti M, Rao $\mathrm{V}$, et al. Hyperglycemia during cardiopulmonary bypass is an independent risk factor for mortality in patients undergoing cardiac surgery. J Thorac Cardiovasc Surg. 2005;130:1144.e1-8.

28. Habib RH, Zacharias A, Schwann TA, Riordan CJ, Durham SJ, Shah A. Adverse effects of low hematocrit during cardiopulmonary bypass in the adult: should current practice be changed? J Thorac Cardiovasc Surg. 2003; 125:1438-50.

29. Fang WC, Helm RE, Krieger KH, Rosengart TK, DuBois WJ, Sason $\mathrm{C}$, et al. Impact of minimum hematocrit during cardiopulmonary bypass on mortality in patients undergoing coronary artery surgery. Circulation. 1997;96(suppl):II194-9.

30. Karkouti K, Djaiani G, Borger MA, Beattie WS, Fedorko L, Wijeysundera $\mathrm{D}$, et al. Low hematocrit during cardiopulmonary bypass is associated with increased risk of perioperative stroke in cardiac surgery. Ann Thorac Surg. 2005;80:1381-7.

31. Kuduvalli M, Oo AY, Newall N, Grayson AD, Jackson M, Desmond $\mathrm{MJ}$, et al. Effect of peri-operative red blood cell transfusion on 30-day and 1-year mortality following coronary artery bypass surgery. Eur J Cardiothorac Surg. 2005;27:592-8.

32. Sedrakyan A, Treasure T, Elefteriades JA. Effect of aprotinin on clinical outcomes in coronary artery bypass graft surgery: a systematic review and meta-analysis of randomized clinical trials. $J$ Thorac Cardiovasc Surg. 2004;128:442-8.

33. Mahoney CB, Lemole GM. Transfusion after coronary artery bypass surgery: the impact of heparin-bonded circuits. Eur J Cardiothorac Surg. 1999;16:206-10.

34. Ranucci M, Mazzucco A, Pessotto R, Grillone G, Casati V, Porreca L, et al. Heparin-coated circuits for high-risk patients: a multicenter, prospective, randomized trial. Ann Thorac Surg. 1999;67: 994-1000.

35. Wiesenack C, Liebold A, Philipp A, Ritzka M, Koppenberg J, Birnbaum DE, et al. Four years' experience with a miniaturized extracorporeal circulation system and its influence on clinical outcome. Artif Organs. 2004;28:1082-8. 


\section{References}

E1. Guidelines and indications for coronary artery bypass graft surgery. A report of the American College of Cardiology/American Heart Association Task Force on Assessment of Diagnostic and Therapeutic Cardiovascular Procedures (Subcommittee on Coronary Artery Bypass Graft Surgery). J Am Coll Cardiol. 1991;17:543-89.

E2. Eagle KA, Guyton RA, Davidoff R, Edwards FH, Ewy GA, Gardner TJ, et al. ACC/AHA 2004 guideline update for coronary artery bypass graft surgery: a report of the American College of Cardiology/American Heart Association Task Force on Practice Guidelines (Committee to Update the 1999 Guidelines for Coronary Artery Bypass Graft Surgery). Circulation. 2004;110:e340-437.

E3. Likosky DS, Leavitt BJ, Marrin CA, Malenka DJ, Reeves AG, Weintraub RM, et al. Intra- and postoperative predictors of stroke after coronary artery bypass grafting. Ann Thorac Surg. 2003;76: 428-35.

E4. Newman MF, Kirchner JL, Phillips-Bute B, Gaver V, Grocott H, Jones RH, et al. Longitudinal assessment of neurocognitive function after coronary-artery bypass surgery. N Engl J Med. 2001;344: 395-402.

E5. Butler J, Rocker GM, Westaby S. Inflammatory response to cardiopulmonary bypass. Ann Thorac Surg. 1993;55:552-9.

E6. Edwards FH, Ferraris VA, Shahian DM, Peterson E, Furnary AP, Haan CK, et al. Gender-specific practice guidelines for coronary artery bypass surgery: perioperative management. Ann Thorac Surg. 2005;79:2189-94.

E7. Bartels C, Gerdes A, Babin-Ebell J, Beyersdorf F, Boeken U, Doenst $\mathrm{T}$, et al. Cardiopulmonary bypass: evidence or experience based? J Thorac Cardiovasc Surg. 2002;124:20-7.

E8. Stammers AH, Mejak BL, Rauch ED, Vang SN, Viessman TW. Factors affecting perfusionists' decisions on equipment utilization: results of a United States survey. J Extra Corpor Technol. 2000; 32:4-10.

E9. Stammers AH, Mejak BL. An update on perfusion safety: does the type of perfusion practice affect the rate of incidents related to cardiopulmonary bypass? Perfusion. 2001;16:189-98.

E10. Mannucci L, Gerometta PS, Mussoni L, Antona C, Parolari A, Salvi $\mathrm{L}$, et al. One month follow-up of haemostatic variables in patients undergoing aortocoronary bypass surgery. Effect of aprotinin. Thromb Haemost. 1995;73:356-61.

E11. Roach GW, Kanchuger M, Mangano CM, Newman M, Nussmeier $\mathrm{N}$, Wolman R, et al. Adverse cerebral outcomes after coronary bypass surgery. Multicenter Study of Perioperative Ischemia Research Group and the Ischemia Research and Education Foundation Investigators. $N$ Engl J Med. 1996;335:1857-63.

E12. Ferguson TB Jr, Hammill BG, Peterson ED, DeLong ER, Grover FL. A decade of change-risk profiles and outcomes for isolated coronary artery bypass grafting procedures, 1990-1999: a report from the STS National Database Committee and the Duke Clinical Research Institute. Society of Thoracic Surgeons. Ann Thorac Surg. 2002;73:480-90.

E13. van der Linden J, Casimir-Ahn H. When do cerebral emboli appear during open heart operations? A transcranial Doppler study. Ann Thorac Surg. 1991;51:237-41.

E14. Hajat C, Hajat S, Sharma P. Effects of poststroke pyrexia on stroke outcome: a meta-analysis of studies in patients. Stroke. 2000;31: 410-4.

E15. Ginsberg MD, Busto R. Combating hyperthermia in acute stroke: a significant clinical concern. Stroke. 1998;29:529-34.

E16. Insler SR, O'Connor MS, Leventhal MJ, Nelson DR, Starr NJ. Association between postoperative hypothermia and adverse outcome after coronary artery bypass surgery. Ann Thorac Surg. 2000;70:175-81.

E17. Nathan HJ, Lavallee G. The management of temperature during hypothermic cardiopulmonary bypass: I-Canadian survey. Can J Anaesth. 1995;42:669-71.

E18. Cook DJ, Orszulak TA, Daly RC, Buda DA. Cerebral hyperthermia during cardiopulmonary bypass in adults. $J$ Thorac Cardiovasc Surg. 1996;111:268-9.

E19. Stone JG, Young WL, Smith CR, Solomon RA, Wald A, Ostapkovich $\mathrm{N}$, et al. Do standard monitoring sites reflect true brain temperature when profound hypothermia is rapidly induced and reversed? Anesthesiology. 1995;82:344-51.

E20. Grocott HP, Newman MF, Croughwell ND, White WD, Lowry E, Reves JG. Continuous jugular venous versus nasopharyngeal temperature monitoring during hypothermic cardiopulmonary bypass for cardiac surgery. J Clin Anesth. 1997;9:312-6.

E21. Johnson RI, Fox MA, Grayson A, Jackson M, Fabri BM. Should we rely on nasopharyngeal temperature during cardiopulmonary bypass? Perfusion. 2002;17:145-51

E22. Salah M, Sutton R, Tsarovsky G, Djuric M. Temperature inaccuracies during cardiopulmonary bypass. J Extra Corpor Technol. 2005;37:38-42.

E23. Newland RF, Sanderson AJ, Baker RA. Accuracy of temperature measurement in the cardiopulmonary bypass circuit. J Extra Corpor Technol. 2005;37:32-7.

E24. McLean RF, Wong BI, Naylor CD, Snow WG, Harrington EM, Gawel M, et al. Cardiopulmonary bypass, temperature, and central nervous system dysfunction. Circulation. 1994;90(suppl):II250-5.

E25. Randomised trial of normothermic versus hypothermic coronary bypass surgery. The Warm Heart Investigators. Lancet. 1994;343: 559-63.

E26. Engelman RM, Pleet AB, Rousou JA, Flack JE 3rd, Deaton DW, Pekow PS, et al. Influence of cardiopulmonary bypass perfusion temperature on neurologic and hematologic function after coronary artery bypass grafting. Ann Thorac Surg. 1999;67:1547-56.

E27. Grigore AM, Mathew J, Grocott HP, Reves JG, Blumenthal JA, White WD, et al. Prospective randomized trial of normothermic versus hypothermic cardiopulmonary bypass on cognitive function after coronary artery bypass graft surgery. Anesthesiology. 2001; 95:1110-9.

E28. Plourde G, Leduc AS, Morin JE, DeVarennes B, Latter D, Symes $\mathrm{J}$, et al. Temperature during cardiopulmonary bypass for coronary artery operations does not influence postoperative cognitive function: a prospective, randomized trial. J Thorac Cardiovasc Surg. 1997;114:123-8.

E29. Birdi I, Regragui I, Izzat MB, Bryan AJ, Angelini GD. Influence of normothermic systemic perfusion during coronary artery bypass operations: a randomized prospective study. J Thorac Cardiovasc Surg. 1997; 114:475-81.

E30. Martin TD, Craver JM, Gott JP, Weintraub WS, Ramsay J, Mora $\mathrm{CT}$, et al. Prospective, randomized trial of retrograde warm blood cardioplegia: myocardial benefit and neurologic threat. Ann Thorac Surg. 1994;57:298-302.

E31. Mora CT, Henson MB, Weintraub WS, Murkin JM, Martin TD, Craver JM, et al. The effect of temperature management during cardiopulmonary bypass on neurologic and neuropsychologic outcomes in patients undergoing coronary revascularization. $J$ Thorac Cardiovasc Surg. 1996;112:514-22.

E32. Regragui I, Birdi I, Izzat MB, Black AM, Lopatatzidis A, Day CJ, et al. The effects of cardiopulmonary bypass temperature on neuropsychologic outcome after coronary artery operations: a prospective randomized trial. J Thorac Cardiovasc Surg. 1996;112: $1036-45$.

E33. Grimm M, Czerny M, Baumer H, Kilo J, Madl C, Kramer L, et al. Normothermic cardiopulmonary bypass is beneficial for cognitive brain function after coronary artery bypass grafting — a prospective randomized trial. Eur J Cardiothorac Surg. 2000;18:270-5.

E34. Gaudino M, Martinelli L, Di Lella G, Glieca F, Marano P, Schiavello R, et al. Superior extension of intraoperative brain damage in case of normothermic systemic perfusion during coronary artery bypass operations. J Thorac Cardiovasc Surg. 1999;118:432-7.

E35. Singh AK, Bert AA, Feng WC, Rotenberg FA. Stroke during coronary artery bypass grafting using hypothermic versus normothermic perfusion. Ann Thorac Surg. 1995;59:84-9.

E36. Christenson JT, Maurice J, Simonet F, Velebit V, Schmuziger M. Normothermic versus hypothermic perfusion during primary coronary artery bypass grafting. Cardiovasc Surg. 1995;3:519-24.

E38. Clark RE, Margraf HW, Beauchamp RA. Fat and solid filtration in clinical perfusions. Surgery. 1975;77:216-24.

E39. Siderys H, Herod GT, Halbrook H, Pittman JN, Rubush JL, Kasebaker V, et al. A comparison of membrane and bubble 
oxygenation as used in cardiopulmonary bypass in patients. The importance of pericardial blood as a source of hemolysis. J Thorac Cardiovasc Surg. 1975;69:708-12.

E40. Brooker RF, Brown WR, Moody DM, Hammon JW Jr, Reboussin DM, Deal DD, et al. Cardiotomy suction: a major source of brain lipid emboli during cardiopulmonary bypass. Ann Thorac Surg. 1998;65:1651-5.

E41. Appelblad M, Engstrom G. Fat contamination of pericardial suction blood and its influence on in vitro capillary-pore flow properties in patients undergoing routine coronary artery bypass grafting. $J$ Thorac Cardiovasc Surg. 2002;124:377-86.

E42. de Vries AJ, Gu YJ, Douglas YL, Post WJ, Lip H, van Oeveren W. Clinical evaluation of a new fat removal filter during cardiac surgery. Eur J Cardiothorac Surg. 2004;25:261-6.

E43. Spanier T, Tector K, Schwartz G, Chen J, Oz M, Beck J, et al Endotoxin in pooled pericardial blood contributes to the systemic inflammatory response during cardiac surgery. Perfusion. 2000;15: 427-31.

E44. Johnell M, Elgue G, Larsson R, Larsson A, Thelin S, Siegbahn A. Coagulation, fibrinolysis, and cell activation in patients and shed mediastinal blood during coronary artery bypass grafting with a new heparin-coated surface. J Thorac Cardiovasc Surg. 2002;124: 321-32.

E45. Weerwind PW, Lindhout T, Caberg NE, De Jong DS. Thrombin generation during cardiopulmonary bypass: the possible role of retransfusion of blood aspirated from the surgical field. Thromb J. 2003;1:3.

E46. Kincaid EH, Jones TJ, Stump DA, Brown WR, Moody DM, Deal $\mathrm{DD}$, et al. Processing scavenged blood with a cell saver reduces cerebral lipid microembolization. Ann Thorac Surg. 2000;70:1296300 .

E47. Likosky DS, Marrin CA, Caplan LR, Baribeau YR, Morton JR, Weintraub RM, et al. Determination of etiologic mechanisms of strokes secondary to coronary artery bypass graft surgery. Stroke. 2003;34:2830-4.

E48. Blauth CI, Cosgrove DM, Webb BW, Ratliff NB, Boylan M, Piedmonte MR, et al. Atheroembolism from the ascending aorta. An emerging problem in cardiac surgery. $J$ Thorac Cardiovasc Surg. 1992;103:1104-12.

E49. Davila-Roman VG, Barzilai B, Wareing TH, Murphy SF, Schechtman KB, Kouchoukos NT. Atherosclerosis of the ascending aorta. Prevalence and role as an independent predictor of cerebrovascular events in cardiac patients. Stroke. 1994;25:2010-6.

E50. Mizuno T, Toyama M, Tabuchi N, Kuriu K, Ozaki S, Kawase I, et al. Thickened intima of the aortic arch is a risk factor for stroke with coronary artery bypass grafting. Ann Thorac Surg. 2000;70: 1565-70.

E51. Djaiani G, Fedorko L, Borger M, Mikulis D, Carroll J, Cheng D, et al. Mild to moderate atheromatous disease of the thoracic aorta and new ischemic brain lesions after conventional coronary artery bypass graft surgery. Stroke. 2004;35:e356-8.

E52. Gold JP, Torres KE, Maldarelli W, Zhuravlev I, Condit D, Wasnick J. Improving outcomes in coronary surgery: the impact of echodirected aortic cannulation and perioperative hemodynamic management in 500 patients. Ann Thorac Surg. 2004;78:1579-85.

E53. Ribakove GH, Katz ES, Galloway AC, Grossi EA, Esposito RA, Baumann FG, et al. Surgical implications of transesophageal echocardiography to grade the atheromatous aortic arch. Ann Thorac Surg. 1992:53:758-62.

E54. Baribeau YR, Westbrook BM, Charlesworth DC, Maloney CT. Arterial inflow via an axillary artery graft for the severely atheromatous aorta. Ann Thorac Surg. 1998;66:33-7.

E55. Taylor KM, Devlin BJ, Mittra SM, Gillan JG, Brannan JJ, McKenna JM. Assessment of cerebral damage during open-heart surgery. A new experimental model. Scand J Thorac Cardiovasc Surg. 1980;14:197-203.

E56. Whitaker D. S100 release as an indicator of cerebral damage. Ann Thorac Surg. 2001;71:2085-6.

E57. Aris A, Solanes H, Camara ML, Junque C, Escartin A, Caralps JM. Arterial line filtration during cardiopulmonary bypass. Neurologic, neuropsychologic, and hematologic studies. J Thorac Cardiovasc Surg. 1986;91:526-33.

E58. Sellman M, Holm L, Ivert T, Semb BK. A randomized study of neuropsychological function in patients undergoing coronary bypass surgery. Thorac Cardiovasc Surg. 1993;41:349-54.

E59. Clark RE, Brillman J, Davis DA, Lovell MR, Price TR, Magovern GJ. Microemboli during coronary artery bypass grafting. Genesis and effect on outcome. J Thorac Cardiovasc Surg. 1995;109: 249-57.

E60. Stump DA, Rogers AT, Hammon JW, Newman SP. Cerebral emboli and cognitive outcome after cardiac surgery. J Cardiothorac Vasc Anesth. 1996;10:113-9.

E61. Murkin JM. Pro: tight intraoperative glucose control improves outcome in cardiovascular surgery. $J$ Cardiothorac Vasc Anesth. 2000;14:475-8

E62. McAlister FA, Man J, Bistritz L, Amad H, Tandon P. Diabetes and coronary artery bypass surgery: an examination of perioperative glycemic control and outcomes. Diabetes Care. 2003;26:1518-24

E63. Finney SJ, Zekveld C, Elia A, Evans TW. Glucose control and mortality in critically ill patients. JAMA. 2003;290:2041-7.

E64. Latham R, Lancaster AD, Covington JF, Pirolo JS, Thomas CS. The association of diabetes and glucose control with surgical-site infections among cardiothoracic surgery patients. Infect Control Hosp Epidemiol. 2001;22:607-12.

E65. Dellinger EP. Preventing surgical-site infections: the importance of timing and glucose control. Infect Control Hosp Epidemiol. 2001; 22:604-6.

E66. Furnary AP, Gao G, Grunkemeier GL, Wu Y, Zerr KJ, Bookin SO, et al. Continuous insulin infusion reduces mortality in patients with diabetes undergoing coronary artery bypass grafting. $J$ Thorac Cardiovasc Surg. 2003;125:1007-21.

E67. Furnary AP, Zerr KJ, Grunkemeier GL, Starr A. Continuous intravenous insulin infusion reduces the incidence of deep sternal wound infection in diabetic patients after cardiac surgical procedures. Ann Thorac Surg. 1999;67:352-60.

E68. Zerr KJ, Furnary AP, Grunkemeier GL, Bookin S, Kanhere V, Starr A. Glucose control lowers the risk of wound infection in diabetics after open heart operations. Ann Thorac Surg. 1997;63:356-61.

E69. Carvalho G, Moore A, Qizilbash B, Lachapelle K, Schricker T. Maintenance of normoglycemia during cardiac surgery. Anesth Analg. 2004;99:319-24.

E70. Ouattara A, Lecomte P, Le Manach Y, Landi M, Jacqueminet S, Platonov I, et al. Poor intraoperative blood glucose control is associated with a worsened hospital outcome after cardiac surgery in diabetic patients. Anesthesiology. 2005;103:687-94.

E71. Garber AJ, Moghissi ES, Bransome ED Jr, Clark NG, Clement S, Cobin RH, et al. American College of Endocrinology position statement on inpatient diabetes and metabolic control. Endocr Pract. 2004;10(suppl 2):4-9.

E72. Groban L, Butterworth J, Legault C, Rogers AT, Kon ND, Hammon JW. Intraoperative insulin therapy does not reduce the need for inotropic or antiarrhythmic therapy after cardiopulmonary bypass. J Cardiothorac Vasc Anesth. 2002;16:405-12.

E73. Karkouti K, Beattie WS, Wijeysundera DN, Rao V, Chan C, Dattilo $\mathrm{KM}$, et al. Hemodilution during cardiopulmonary bypass is an independent risk factor for acute renal failure in adult cardiac surgery. J Thorac Cardiovasc Surg. 2005;129:391-400.

E74. Swaminathan M, Phillips-Bute BG, Conlon PJ, Smith PK, Newman MF, Stafford-Smith M. The association of lowest hematocrit during cardiopulmonary bypass with acute renal injury after coronary artery bypass surgery. Ann Thorac Surg. 2003;76:784-92.

E75. McCusker K, Vijay V, DeBois W, Helm R, Sisto D. MAST system: a new condensed cardiopulmonary bypass circuit for adult cardiac surgery. Perfusion. 2001;16:447-52.

E76. Cormack JE, Forest RJ, Groom RC, Morton J. Size makes a difference: use of a low-prime cardiopulmonary bypass circuit and autologous priming in small adults. Perfusion. 2000;15:129-35.

E77. Beholz S, Zheng L, Kessler M, Rusche M, Konertz W. A new PRECiSe (Priming Reduced Extracorporeal Circulation Setup) minimizes the need for blood transfusions: first clinical results in coronary artery bypass grafting. Heart Surg Forum. 2005;8:E132-5. 
E78. van Boven WJ, Gerritsen WB, Waanders FG, Haas FJ, Aarts LP. Mini extracorporeal circuit for coronary artery bypass grafting: initial clinical and biochemical results: a comparison with conventional and off-pump coronary artery bypass grafts concerning global oxidative stress and alveolar function. Perfusion. 2004;19: 239-46.

E79. Takai H, Eishi K, Yamachika S, Hazama S, Nishi K, Ariyoshi T, et al. The efficacy of low prime volume completely closed cardiopulmonary bypass in coronary artery revascularization. Ann Thorac Cardiovasc Surg. 2004;10:178-82.

E80. Shapira OM, Aldea GS, Treanor PR, Chartrand RM, DeAndrade KM, Lazar HL, et al. Reduction of allogeneic blood transfusions after open heart operations by lowering cardiopulmonary bypass prime volume. Ann Thorac Surg. 1998;65:724-30.

E81. Rosengart TK, DeBois W, O'Hara M, Helm R, Gomez M, Lang SJ, et al. Retrograde autologous priming for cardiopulmonary bypass: a safe and effective means of decreasing hemodilution and transfusion requirements. J Thorac Cardiovasc Surg. 1998; 115:426-39.

E82. Balachandran S, Cross MH, Karthikeyan S, Mulpur A, Hansbro $\mathrm{SD}$, Hobson P. Retrograde autologous priming of the cardiopulmonary bypass circuit reduces blood transfusion after coronary artery surgery. Ann Thorac Surg. 2002;73:1912-8.

E83. Petry AF, Jost J, Sievers H. Reduction of homologous blood requirements by blood-pooling at the onset of cardiopulmonary bypass. J Thorac Cardiovasc Surg. 1994;107:1210-4.

E84. Speiss BD. Transfusion and outcome in heart surgery. Ann Thorac Surg. 2002;74:986-7.

E85. Chelemer SB, Prato BS, Cox PM Jr, O'Connor GT, Morton JR. Association of bacterial infection and red blood cell transfusion after coronary artery bypass surgery. Ann Thorac Surg. 2002;73: $138-42$.

E86. Leal-Noval SR, Rincon-Ferrari MD, Garcia-Curiel A, HerruzoAviles A, Camacho-Larana P, Garnacho-Montero J, et al. Transfusion of blood components and postoperative infection in patients undergoing cardiac surgery. Chest. 2001;119:1461-8.

E87. Habib RH, Zacharias A, Schwann TA, Riordan CJ, Engoren M, Durham SJ, et al. Role of hemodilutional anemia and transfusion during cardiopulmonary bypass in renal injury after coronary revascularization: implications on operative outcome. Crit Care Med. 2005;33:1749-56.

E88. Vamvakas EC, Carven JH. RBC transfusion and postoperative length of stay in the hospital or the intensive care unit among patients undergoing coronary artery bypass graft surgery: the effects of confounding factors. Transfusion. 2000;40:832-9.

E89. Fransen E, Maessen J, Dentener M, Senden N, Buurman W. Impact of blood transfusions on inflammatory mediator release in patients undergoing cardiac surgery. Chest. 1999;116:1233-9.

E90. Michalopoulos A, Tzelepis G, Dafni U, Geroulanos S. Determinants of hospital mortality after coronary artery bypass grafting. Chest. 1999;115:1598-603.

E91. Engoren MC, Habib RH, Zacharias A, Schwann TA, Riordan CJ, Durham SJ. Effect of blood transfusion on long-term survival after cardiac operation. Ann Thorac Surg. 2002;74:1180-6.

E92. Kirklin JK, Westaby S, Blackstone EH, Kirklin JW, Chenoweth $\mathrm{DE}$, Pacifico AD. Complement and the damaging effects of cardiopulmonary bypass. J Thorac Cardiovasc Surg. 1983;86:845-57.

E93. Ascione R, Lloyd CT, Underwood MJ, Lotto AA, Pitsis AA, Angelini GD. Inflammatory response after coronary revascularization with or without cardiopulmonary bypass. Ann Thorac Surg. 2000;69:1198-204.
E94. Ishikawa M, Zhang JH, Nanda A, Granger DN. Inflammatory responses to ischemia and reperfusion in the cerebral microcirculation. Front Biosci. 2004;9:1339-47.

E95. Striggow F, Riek-Burchardt M, Kiesel A, Schmidt W, HenrichNoack P, Breder J, et al. Four different types of protease-activated receptors are widely expressed in the brain and are up-regulated in hippocampus by severe ischemia. Eur J Neurosci. 2001;14:595608.

E96. Baufreton C, Allain P, Chevailler A, Etcharry-Bouyx F, Corbeau JJ, Legall D, et al. Brain injury and neuropsychological outcome after coronary artery surgery are affected by complement activation. Ann Thorac Surg. 2005;79:1597-605.

E97. Asimakopoulos G, Thompson R, Nourshargh S, Lidington EA, Mason JC, Ratnatunga CP, et al. An anti-inflammatory property of aprotinin detected at the level of leukocyte extravasation. J Thorac Cardiovasc Surg. 2000;120:361-9.

E98. Saito N, Motoyama S, Sawamoto J. Effects of new polymer-coated extracorporeal circuits on biocompatibility during cardiopulmonary bypass. Artif Organs. 2000;24:547-54.

E99. Videm V, Svennevig JL, Fosse E, Semb G, Osterud A, Mollnes TE. Reduced complement activation with heparin-coated oxygenator and tubings in coronary bypass operations. $J$ Thorac Cardiovasc Surg. 1992;103:806-13.

E100. Fromes Y, Gaillard D, Ponzio O, Chauffert M, Gerhardt MF, Deleuze $\mathrm{P}$, et al. Reduction of the inflammatory response following coronary bypass grafting with total minimal extracorporeal circulation. Eur J Cardiothorac Surg. 2002;22:527-33.

E101. Moen O, Hogasen K, Fosse E, Dregelid E, Brockmeier V, Venge P, et al. Attenuation of changes in leukocyte surface markers and complement activation with heparin-coated cardiopulmonary bypass. Ann Thorac Surg. 1997;63:105-11.

E102. Defraigne JO, Pincemail J, Dekoster G, Larbuisson R, Dujardin M, Blaffart F, et al. SMA circuits reduce platelet consumption and platelet factor release during cardiac surgery. Ann Thorac Surg. 2000;70:2075-81.

E103. Rubens FD, Labow RS, Lavallee GR, Watson MI, Robblee JA, Voorhees ME, et al. Hematologic evaluation of cardiopulmonary bypass circuits prepared with a novel block copolymer. Ann Thorac Surg. 1999;67:689-96.

E104. Dickinson T, Mahoney CB, Simmons M, Marison A, Polanski P. Trillium-coated oxygenators in adult open-heart surgery: a prospective randomized trial. J Extra Corpor Technol. 2002;34:248-53.

E105. McCarthy PM, Yared JP, Foster RC, Ogella DA, Borsh JA, Cosgrove DM 3rd. A prospective randomized trial of Duraflo II heparin-coated circuits in cardiac reoperations. Ann Thorac Surg. 1999; 67:1268-73

E106. Mongero LB, Beck JR, Manspeizer HE, Heyer EJ, Lee K, Spanier TA, et al. Cardiac surgical patients exposed to heparin-bonded circuits develop less postoperative cerebral dysfunction than patients exposed to non-heparin-bonded circuits. Perfusion. 2001;16: 107-11.

E107. Muehrcke DD, McCarthy PM, Kottke-Marchant K, Harasaki H, Pierre-Yared J, Borsh JA, et al. Biocompatibility of heparin-coated extracorporeal bypass circuits: a randomized, masked clinical trial. J Thorac Cardiovasc Surg. 1996;112:472-83.

E108. Heyer EJ, Lee KS, Manspeizer HE, Mongero L, Spanier TB, Caliste X, et al. Heparin-bonded cardiopulmonary bypass circuits reduce cognitive dysfunction. J Cardiothorac Vasc Anesth. 2002; $16: 37-42$.

E109. Mahoney CB. Heparin-bonded circuits: clinical outcomes and costs. Perfusion. 1998;13:192-204. 